http://kitaibelia.unideb.hu/

ISSN 2064-4507 (Online) • ISSN 1219-9672 (Print)

(C) Department of Botany, University of Debrecen, Hungary

23 (2): 155-169.; 2018

DOI: $10.17542 /$ kit.23.155

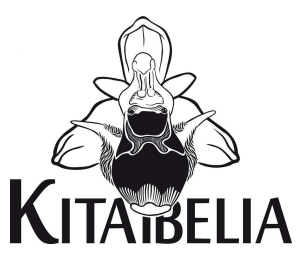

\title{
Adatok az Arabis nemorensis (Cruciferae) hazai elterjedéséhez
}

\author{
SOMLYAY Lajos \\ MTM Növénytár, H-1431 Budapest, Pf. 137.; somlyay.lajos@nhmus.hu
}

\section{Contributions to the distribution of Arabis nemorensis (Cruciferae) in Hungary}

\begin{abstract}
Arabis nemorensis is a poorly-known species with sparse and mostly uncertain literature records in Hungary. A complete list of its known occurrences was presented in Soó's synopsis in 1968. A few new records of this taxon have been reported since then. In the present study all literature records were evaluated by means of revision of Hungarian herbarium materials. Several vouchers were succesfully traced, and their identity as A. nemorensis was confirmed (Baja, Ercsi, Lesenceistvánd, Miskolc, Nagykanizsa, Szigetújfalu). In other cases, the putative vouchers belonged to A. hirsuta or A. sagitatta, thus the corresponding literature records proved to be erroneous (Balatonmáriafürdő-alsó, Gyenesdiás, Kőszeg, Vasboldogasszony, Zalaújlak). On the other hand, hitherto unknown Hungarian localities of $A$. nemorensis were revealed, specifically in the Bükk Mts. (Eger, Kács), the Bakony Mts. (Márkó), in the western Balaton region (Hahót, Hévíz, Keszthely-Fenékpuszta, Nyirád, Tapolca) and the Hungarian Plains (Csákvár, Debrecen, Egeralja, Fertőd-Eszterháza, Kiskőrös, Lébény, Ócsa, Sárszentmihály, Szigetszentmiklós). The species appeared to be new for the phytogeographical regions Bakonyicum and Nyírségense. Additionally, a few specimens of $A$. nemorensis collected outside the territory of present-day Hungary were revised in BP. The historical occurrence of the species at Torja (Turia in Romania) is documented by two specimens (Schur, 1853, as A. gerardi; Jávorka \& Keller, 1943, as A. hirsuta). Another specimen that was collected in 1879 at Óbecse (Bečej) and labelled as $A$. glastifolia by Kovács was found to be A. nemorensis too. Since the identity of Schneller's literature record (1858) from Futak is uncertain, Kovács's specimen is currently the only, though historical record of this species from Vojvodina province in Serbia. Further specimens of $A$. nemorensis were discovered in the collections of Lengyel. They were collected and labelled as A. sagittata near Pomogy (Pamhagen) in 1910 (and questionably in 1919), probably representing the first gathering of $A$. nemorensis from Burgenland state in Austria.
\end{abstract}

Keywords: Arabis, Austria, distribution, flora, Hungary, Romania, Serbia

Összefoglalás - Az A. nemorensis a magyar flóra hiányosan ismert tagja, szórványos és zömmel bizonytalan adatokkal az ország területéről. Hazai lelőhelyeinek legteljesebb listája Soó szinopszisában jelent meg 1968-ban. Azóta csak néhány adatát publikálták. Jelen dolgozat a magyar herbáriumokban lévő anyagok revíziójának tükrében értékeli a faj hazai irodalmi adatait. Néhány irodalmi adat (Baja, Ercsi, Lesenceistvánd, Miskolc, Nagykanizsa, Szigetújfalu) bizonyító példánya előkerült. Egyes esetekben a föltételezhető bizonyító példány $A$. hirsuta-nak vagy $A$. sagittata-nak bizonyult, így a vonatkozó irodalmi adatok tévesnek tekinthetők (Balatonmáriafürdő-alsó, Gyenesdiás, Kőszeg, Vasboldogasszony, Zalaújlak). Ugyanakkor az A. nemorensis-nek publikálatlan vagy tévesen határozott példányait is azonosítottam, így a fajnak új előfordulásaira derült fény a Bükk hegységből (Eger, Kács), a Bakonyból (Márkó), a Balaton nyugati térségéből (Hahót, Hévíz, Keszthely-Fenékpuszta, Nyirád, Tapolca) és az Alföldről (Csákvár, Debrecen, Egeralja, Fertőd-Eszterháza, Kiskőrös, Lébény, Ócsa, Sárszentmihály, Szigetszentmiklós). Ezek alapján a faj újnak bizonyult a Dunántúli-középhegységre (Bakonyicum) és a Tiszántúlra, utóbbin belül a Nyírségense flórajárásra. A Növénytár herbáriumában néhány, a történelmi Magyaror- 
szág területéről származó $A$. nemorensis példányt is revideáltam. A faj egykori előfordulása Torja mellett (ma: Turia község Romániában) két példánnyal is bizonyított (Schur, 1853, A. gerardi néven; Jávorka \& Keller, 1943, A. hirsuta néven). Egy másik példány, amelyet Kovács Ferenc gyüjtött 1879-ben Óbecse (ma: Bečej Szerbiában) mellett, és A. glastifolia-ként cédulázott, szintén A. nemorensis-nek bizonyult. Miután Schneller Futak mellől származó irodalmi adatának (1858) azonossága bizonytalan, jelenleg Kovács példánya a faj egyetlen ismert, bár történeti értékű adata a Vajdaság területéről. A ma Ausztriához tartozó Ốrvidéken, Pomogy (Pamhagen, Burgenland) közelében Lengyel Géza gyűjtötte a növényt 1910-ben (a másik példányán szereplő 1919-es dátum kérdéses), amelyet $A$. sagittata néven cédulázott. Történetileg valószínűleg ez az A. nemorensis első adata az Őrvidék területéről.

Kulcsszavak: Arabis, Ausztria, elterjedés, flóra, Magyarország, Románia, Szerbia

\section{Bevezetés}

Az Arabis nemorensis (Hoffm.) W. D. J. Koch [syn. Turritis gerardi Bess., Arabis hirsuta (L.) Scop. ssp. gerardi (Bess.) Hartm. f., A. gerardii (Bess.) Bess. ex Koch, A. planisiliqua (Pers.) Rchb. ssp. nemorensis (Hoffm.) Soják] a morfológiailag igen változatos A. hirsuta fajcsoport kevéssé ismert tagja, amelyet Turritis nemorensis néven 1804-ben írtak le (HofFMANN 1804). Jóllehet a faj leírása óta több mint kétszáz év telt el, a botanikusok jelentős része sokáig különböző Arabis fajok infraspecifikus taxonjaként kezelte (alfaj, változat vagy forma rangon). Faji státusza, főként TiTz $(1969 a, 1969 b, 1972,1976)$ eredményeinek köszönhetően, csak az utóbbi évtizedekben vált általánosan elfogadottá (pl. DOMAC 2002, ŠTĚPÁNEK et al. 2002, FISCHER et al. 2005, CiOCÂRLAN 2009, JÄGER 2017). Az újabb keletű munkák közül JALAS \& SUOMINEN (1994) az A. planisiliqua alfajaként tárgyalta, de miután az „alfajok" morfológiailag, ökológiailag, areálgeográfiailag és molekuláris alapon (KARL \& KoCH 2014) is különböznek, az A. nemorensis és az A. planisiliqua elválasztása faji rangon indokolt.

Növényünk JALAS \& SUOMINEN (1994) térképe alapján közép- és kelet-európai elterjedésú, kontinentális jellegü taxon, diagnosztikus bélyegeit többek között TITz (1969a, még $A$. planisiliqua néven, vö. Tiтz 1976) és a felsorolt szakirodalom tartalmazza. A xerofil hazai rokon fajoktól [A. hirsuta s.str., A. sagittata (Bertol.) DC.] eltérően higrofil növény, folyók mentén, nedves réteken, láp- és mocsárerdőkben, erdőnyiladékokban fordul elő, elsősorban az alföldön, de hegyvidéken is (pl. TITZ 1972, TITZ 1976, KARL \& KoCH 2014).

A 19. századi szinoptikus munkák (NEILREICH 1866, 1870, HAZSLINSZKY 1872) növényünket csak a Bánságból említették (Arabis gerardi Bess. néven), hazánk jelenlegi területéről nem. KERNER (1867) és BORBÁs (1878) sem tárgyalták, pedig Borbás dolgozatának jelentős részét az Arabis nemzetség hazai képviselőinek szentelte. A faj első ismert csonkaországi gyűjtése (BP 231473) Tauscher Gyula nevéhez füződik (1868, Szigetújfalu, taxonnév nélkül, rev. Somlyay). MENYHÁRT (1877: 37) a kalocsai flóraművében „A. glastifolia Rchb.”-t közölt a Kalocsa melletti Selyem-erdőből. A jelzett élőhely (,árnyas ligetekben”) alapján az adat föltehetően a növényünkre vonatkozik, herbáriumi példányát nem találtam. BoRBÁs (1879) Szigetújfaluról jelezte (Arabis gerardi Bess. néven), ez biztos adatnak tekinthető (vö. Tuzson 1916). WALLNER (1903) A. gerardi néven közölt irodalmi adata Sopron mellől a megadott élőhely („erdős dombokon”) miatt bizonyára valamelyik xerofil rokon fajra vonatkozik.

$\mathrm{Az}$ A. hirsuta fajcsoport hazai elterjedésének tisztázásában fontos lépést jelentettek Tuzson $(1916,1921)$ dolgozatai, bár a teljes alakkört figyelembe véve is mindössze forma rangú elkülönítést talált indokoltnak. Növényünket $A$. hirsuta f. gerardi (Bess.) Tuzson néven tárgyalta, kitűnő rajzát is mellékelve (TuzSoN 1916: 422), amelyen a szár jellegzetes meze és a szárhoz simuló sűrü levélzet élethűen mutatkozik. [Sajnos a KIRÁLY et al. (2011) munkájában közölt ábra, különösen a részletrajzok nem igazán sikerültek, a legfontosabb határozóbélyeg, a szár szőrzete pedig ki sincs emelve.] Tuzson (1916: 425) tisztázta, hogy Tauscher „A. hirsuta"-gyüjtéseinek egy része (Szigetúffalu, Ercsi) e taxonra (azaz A. nemorensis-re) vonat- 
kozik. Ugyancsak látta Borbás (Szigetúffalu, Dunapataj) és Wiesbaur (Kalocsa) vonatkozó bizonyító példányait, én sajnos nem leltem ezeket a Növénytár herbáriumában.

JáVORKA (1924-1925) flóraművében a növény Arabis hirsuta [ssp.] nemorensis (Wolf.) Hay. néven paragrafustaxonként szerepel, de lelőhelyet nem ad. A mű mai Magyarország területére adaptált „kis határozó” változatában (JÁvORKA 1926, 1937) már nem is vette fel. Ennek ellenére az 1930-as években újabb hazai lelőhelyeit publikálták: Soó (1930, A. hirsuta ssp. nemorensis néven) Gyenesdiás és Lesenceistvánd mellől, KISS (1939, A hirsuta var. nemorensis néven) a hejcei Fónyi-erdőből közölte. A taxon elnevezésében itt még JáVORKA (1924-1925: 434) hatása érvényesült.

JávoRKA \& Soó (1951: 619) növényünket - föltehetően DosTÁL (1948-1950: 302) hatására, habár ezt a kiváló munkát a kézikönyv irodalmi áttekintése (vö. XXXV) még csak nem is említi - már A. hirsuta ssp. planisiliqua (Pers.) Thell. néven szerepelteti. A kézikönyv a következőket írja hazai előfordulásáról: „elterjedése megállapítandó ... ritka (pl. Dunam.: Csepelsz.Kalocsa, Balatonv.)". Itt tehát Tuzson (1916) és Soó (1930) adatai összegződtek. Fontos megemlíteni, hogy az idő tájt nemcsak a növény elterjedése, hanem élőhely-preferenciája is ismeretlen volt idehaza. A kézikönyv „Quercetalia-Festuco-Brometea erdős-sztyepnövény” cönológiai jellemzése csak az A. hirsuta (s. str.) és az alá vont „var. sagittata (Bert.) Rchb.” taxonokra vonatkoztatható, növényünkre semmi esetre sem.

A taxon egy újabb publikált (Kovács \& PrISZTER 1957: Pécel) és publikáltalan déldunántúli adatainak (lásd később) birtokában Soó (1968, ezúttal $A$. hirsuta ssp. gerardi néven) szinopszisa az addigi (és egyben a jelenlegi) legteljesebb lelőhelyi listát közölte, amelyet szöveghüen idézek: „ÉK (pl. Sátor-hg., Bükk), DK (pl. Balaton-v.), NyDt (Kőszeg), DDt (É- és D-Zala, Balaton-part), A (főleg Duna-v., D-T: Pécel, bizonnyal másutt is)". A szinopszis már „láprétek”, ill. „Molinion” társulások karakterfajaként jellemzi növényünket, megjegyezve, hogy „hazai adat nincs”. Valóban, Kovács (1962) alapvető monográfiájának cönológiai tabelláiból, amelyeket Soó nyilván átnézett, hiányzik e taxon.

A szinopszis megjelenése óta eltelt fél évszázadban növényünknek csak egy-két újabb hazai adatát publikálták (STETÁK 2005, KIRÁLY \& KIRÁLY 2006). E meglepő tény bizonyára nemcsak a 20. század utolsó évtizedeiben a hazai florisztikára jellemző pangásnak tudható be, hanem annak is, hogy az ezredforduló magyar határozókönyvei (SIMON 1992, 2000) e taxont infraspecifikus rangon sem tárgyalták. Utóbbi okból igen valószínűnek tartom, hogy az elmúlt évtizedekben néhány, nedves élőhelyről publikált „Arabis hirsuta” előfordulás (pl. LÁjER 2007) valójában A. nemorensis-t takar. Kéziratom lezárásakor (2018 augusztusa) jelent meg a Botanikai Közlemények idei első füzetének elektronikus verziója, amelyben KIRÁLY \& KIRÁLY (2018) a faj néhány újabb hazai előfordulását közlik. Sajnálatos, hogy bár a cikk szerzői kiemelten fontosnak tartják az „archív adatok feltárását”, saját $A$. nemorensis adataik értékelésekor a közgyüjteményekben elhelyezett herbáriumi anyagot figyelmen kívül hagyták.

\section{Anyag és módszer}

Dolgozatomban számos hazai herbárium (BP, BPU, DE, GK, GYÖ, JPU, KBM, SAMU, SZIE, ZIRC) releváns Arabis-anyagának revíziója, illetve a revideált anyagnak a szakirodalmi adatokkal, elsősorban a szinopszis (Soó 1968) listájával való egybevetése révén arra teszek kísérletet, hogy a faj magyarországi elterjedéséről a jelenleginél pontosabb képet nyújtsak, s ezzel további kutatásokat ösztönözzek. A fenti herbáriumok közül kettő anyagához megjegyzést kell füznöm. KIRÁLY \& KIRÁLY (2018) szerint az általuk közölt öt $A$. nemorensis előfordulásból kettő bizonyító példányát az MTM Növénytárában helyezték el. Bár a cikk aránylag régi gyűjtésekre utal (Lébény - 1999, Ócsa - 2004), kéziratom lezárásáig ezek nem kerültek be a törzsgyűjteménybe. A másik furcsa eset a Mátra Múzeum anyagát érinti. Az A. hirsuta fajcsoport- 
ból NAGY (2006) áttekintése mindössze egyetlen (!) Gotthárd-gyűjtést (Ócsa, 1985) jelez. Ugyanakkor a múzeum adatbázisa 32 releváns példányt tartalmaz, 36 került elő, de az említett ócsai gyűjités nem (Ballók in litt.).

A herbáriumi akronimok az Index Herbariorum (http://sweetgum.nybg.org/science/ih/) jelenlegi adatbázisának felelnek meg, az abból hiányzó hazai herbáriumokat ideiglenes akronimmal jelöltem (Mátra Múzeum, Gyöngyös = GYÖ, Szent István Egyetem, Gödöllő = SZIE, Bakonyi Természettudományi Múzeum = ZIRC). A dolgozatban alkalmazott egyéb rövidítések a következők: s.coll. = sine collectore (gyüjtő neve nélkül), s.n. = sine numero (példányazonosító nélkül).

Egyes esetekben, különösen, ha csak a településnév volt ismert, a faj lelőhelyének KEFkvadrátba sorolása nehézségbe ütközött, ezért az 1. ábrán némelyik szimbólum nem feltétlenül a valós, hanem esetleg valamelyik szomszédos kvadrátban helyezkedik el.

\section{A herbáriumi revízió eredményei}

Amint az várható volt, az összesen talált 35 A. nemorensis példányból a legtöbb ( $24 \mathrm{db})$ a $\mathrm{BP}$, négy a DE, három a GYÖ, egy-egy pedig a BPU, JPU, KBM és ZIRC herbáriumából került elő (1. táblázat).

1. táblázat. A megvizsgált herbáriumokban talált hazai A. nemorensis példányok és azok fontosabb adatai. A példányok a települések abc-rendjében, egyazon település esetén időrendben következnek egymás után. A csillaggal jelölt példányokat Tuzson (1916) „A. hirsuta f. gerardi” néven közölte.

Table 1. Main data of vouchers of Arabis nemorensis from Hungary traced or revised by the author in the checked herbaria. Specimens are arranged in alphabetical order of settlements, and in chronological order within settlements. Specimens marked by asterisks were cited by Tuzson (1916) as „A. hirsuta f. gerardi".

\begin{tabular}{lllllll}
\hline & & & & & \\
& & & &
\end{tabular}




\begin{tabular}{|c|c|c|c|c|c|c|}
\hline 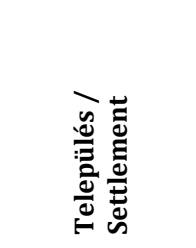 & 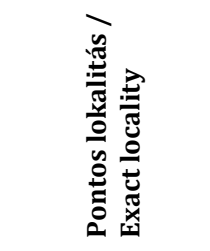 & 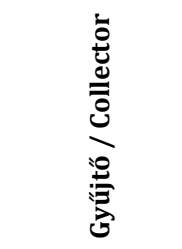 &  & 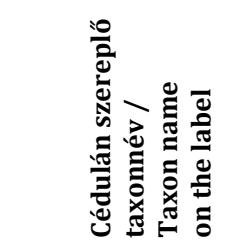 &  & $\frac{\text { 권 }}{\frac{1}{y}}$ \\
\hline Kács & Kácsfürdő & Lengyel & VI.1949 & Arabis hirsuta & BP 355021 & 8089.2 \\
\hline $\begin{array}{l}\text { Keszthely- } \\
\text { Fenékpuszta }\end{array}$ & Diás-sziget & Máthé & 10.VI.1945 & Turritis glabra & BP 718395 & 9369.1 \\
\hline Kiskőrös & Tabdi-erdő & Boros & 17.V.1925 & - & BP 429395 & 9381.2 \\
\hline Lesenceistvánd & - & Soó & 4.VI.1928 & $\begin{array}{l}\text { Arabis hirsuta } \\
\text { ssp. sagittata } \\
\text { f. longisiliqua }\end{array}$ & KBM 4101 & 9170.1 \\
\hline Lébény & Bormászi-erdő & Polgár & 30.V.1926 & $\begin{array}{l}\text { Arabis hirsuta } \\
\text { ssp. planisiliqua }\end{array}$ & $\begin{array}{l}\text { BP } 262 \ldots, \\
\text { BP } 262674, \\
\text { DE s.n. }\end{array}$ & 8270.3 \\
\hline Márkó & Csapberki-erdő & Pillitz & 5.VI.1901 & Arabis glabra & BP 252122 & 8872.4 \\
\hline Miskolc & Garadna-völgy & Károlyi & 16.VII.1961 & Arabis hirsuta & BP 298106 & 7889.4 \\
\hline Nagykanizsa & - & Károlyi & 28.V.1949 & Arabis hirsuta & BP 298111 & 9567.4 \\
\hline Nyirád & Sárosfői-erdő & Gotthárd & 20.V.1974 & $\begin{array}{l}\text { Arabis hirsuta } \\
\text { ssp. sagittata }\end{array}$ & GYÖ s.n. & 8970.4 \\
\hline Ócsa & - & Soó \& Borsos & 10.VI.1953 & Arabis hirsuta & BPU s.n. & 8781.1 \\
\hline Ócsa & Ócsai szőlők & Gotthárd & 14.VI.1980 & Arabis hirsuta & GYÖ s.n. & 8781.2 \\
\hline Sárszentmihály & Hermina-puszta & $\begin{array}{c}\text { Filarszky \& } \\
\text { Kümmerle }\end{array}$ & 8.V.1923 & Arabis nemorensis & BP 73145 & 8875.2 \\
\hline Sárszentmihály & - & Sramkó & 24.V.2009 & Arabis hirsuta & DE s.n. & 8875.2 \\
\hline $\begin{array}{l}\text { Szigetszent- } \\
\text { miklós }\end{array}$ & - & Lengyel & 21.V.1933 & Arabis hirsuta & $\begin{array}{l}\text { BP } 355024, \\
\text { BP } 355025\end{array}$ & 8680.3 \\
\hline Szigetújfalu & - & Tauscher & 1868 & - & BP 231473 & 8779.4 \\
\hline Szigetújfalu & - & Tauscher & 14.V.1871 & Arabis hirsuta & BP 73180* & 8779.4 \\
\hline Szigetújfalu & - & Tauscher & 24.V.1875 & Arabis hirsuta & BP 73037 & 8779.4 \\
\hline Szigetújfalu & - & Vajda & 10.V.1936 & Arabis hirsuta & BP 286275 & 8779.4 \\
\hline Tapolca & - & Lengyel & 15.VI.1914 & Arabis sagittata & BP 355258 & 9170.2 \\
\hline
\end{tabular}

\section{Magyarországi áttekintés Soó (1968) szinopszisa tükrében}

A következőkben áttekintem a faj publikált és publikálatlan (herbáriumi) hazai adatait. A tárgyalásban Soó (1968) területi csoportosítását követem, amely növényföldrajzi megközelítésű (vö. Soó 1960). A herbáriumi revízió tükrében kritikailag értékelem a vonatkozó szakirodalmat, kiegészítve a téves határozás miatt eddig rejtve maradt herbáriumi adatokkal. A formálisan nem publikált, de JALAS \& SUOMINEN (1994) térképén többé-kevésbé azonosítható előfordulásokat is tárgyalom. Fő megállapításaimat az 1. ábra összegzi.

\section{Északi-középhegység (Matricum)}

A Soó (1968) által jelzett sátor-hegységi adat nyilvánvalóan KISS (1939: 218) flóraművén alapul, aki a taxont a hejcei Fónyi-erdőből jelezte (A. hirsuta var. nemorensis néven). Soó (1940) és 
a későbbi szakirodalom a területről nem említi. Habár Kiss Árpád példánya eddig nem került elő, a megadott élőhely alapján a hejcei adat föltehetően korrekt.

Nem egyértelmű azonban, miként került a „Bükk” mint lelőhely Soó (1968) szinopszisába, a taxonnak ugyanis nincs korábbi publikált adata a hegységből (vö. Tuzson 1916, Soó 1943, JÁVORKA \& Soó 1951). Egyetlen lehetséges magyarázatként az az Arabis hirsuta-ként cédulázott példány kínálkozik, amelyet Károlyi Árpád a Garadna-völgyben gyűjtött 1961-ben („In graminosis vallis rivuli Garadna-patak dit. pr. pag. Hámor”, BP 298106). A példányt utólag ismeretlen személy (valószínűleg Pócs Tamás vagy Balogh Márton) ceruzával „ssp. gerardi”ként revideálta. Elképzelhető, hogy a revideált adat személyes közlés révén Soó tudomására jutott, s így került be a hegység a szinopszis elterjedési adatai közé (lásd még a Dunántúliközéphegység és a Dél-Dunántúl fejezeteknél írottakat). A jóval későbbi Bükk-monográfia (VojTKó 2001: 201) kizárólag az említett példányt idézi. A revízió helyességéről meggyőződtem, Károlyi gyűjtése valóban $A$. nemorensis. Emellett azonban a fajnak a Bükk déli peremvidékéről (Eger: Berva-völgy, Nagy-Eged; Kács: Kácsfürdő) származó, eddig nem felismert példányait is sikerült azonosítanom a Növénytár herbáriumában (1. táblázat). Mindhárom, $A$. hirsuta-ként cédulázott lap Lengyel Géza gyűjtése az 1940-es évekből (BP 355021, BP 355022, BP 355023).

A fenti adatokból kitűnik, hogy növényünk az Északi-középhegység régiójában eddig csak az Alfölddel határos peremterületeken került elő.



1. ábra. Az A. nemorensis magyarországi adatainak értékelése (2018. augusztusi állapot). Telt kör: herbáriumi példánnyal igazolt előfordulás. Üres kör: föltehetően korrekt irodalmi adat, amelynek bizonyító példányát a szerző nem látta. Kereszt: valószínűleg vagy biztosan téves adat.

Fig. 1. Evaluation of Hungarian records of Arabis nemorensis (August 2018). Filled circle: record supported by voucher. Hollow circle: probably correct literature record the voucher of which was not available to the author. Cross: probably or certainly erroneous record. 
Dunántúli-középhegység (Bakonyicum)

Megnehezíti az értékelést, hogy Soó (1968) a Dunántúli-középhegységből csak a Balatonvidéket konkretizálta, azt is csak példaként említve. E szerint a növénynek máshol is elő kéne fordulnia a területen, amelyet tudtommal semmilyen korábbi irodalmi adat vagy herbáriumi példány nem támaszt alá. A Balaton északi partvidékén a taxonra vonatkoztatható publikált adatok, mint említettem, Gyenesdiás és Lesenceistvánd mellől származnak [Soó (1930: 175), A. hirsuta ssp. nemorensis és (A. hirsuta ssp. nemorensis) f. glastifolia néven]. Az átnézett hazai herbáriumokban két olyan példányt találtam, amelyek Soó (1930) közlésének alapjául szolgálhattak, habár a példányokon és a cikkben használt taxonnevek nem egyeznek (e jelenség Soó munkásságában nem példa nélküli). Az egyik példány a Debreceni Egyetem herbáriumában található („,in silvis montis Messzelátó pr. pagum Gyenesdiás”, Soó, 3.VI.1928, DE s.n., A. hirsuta var. glastifolia néven) (vö. TAKÁcs et al. 2014). Ez a példány biztosan nem $A$. nemorensis, hanem a xerofil rokon fajok egyike. A másik lapot a keszthelyi Balatoni Múzeum herbáriuma őrzi („pr. pagum Lesenceistvánd”, Soó, 4.VI.1928, KBM 4101, A. hirsuta ssp. sagittata f. longisiliqua néven) (vö. NAGY et al. 2016). Habár ez a példány történetesen $A$. nemorensis, a lelőhely növényföldrajzilag nem vonható a Dunántúli-középhegységhez.

Megemlítem, hogy a Növénytárban egy, a Tihanyi-félszigetről származó, A. hirsuta-ként cédulázott példányt is találtam Károlyi Árpád gyűjtéseiből (26.V.1948, BP 298113), amelyet Balogh Márton utóbb ceruzával „ssp. gerardi” néven revideált (a példány valójában $A$. sagittata). Balogh revíziója - hasonlóan a bükki adathoz - esetleg Soó tudomására juthatott, megerősítve őt abbéli hitében, hogy növényünk előfordul a Balaton környékén. Habár a nagy méretarány miatt nehéz biztosat mondani, de JALAS \& SUOMINEN (1994) térképén valószínűleg szerepel a tihanyi pont. Az elmondottak tükrében viszont a fajnak egyetlen korábbi hiteles adata sincs a Dunántúli-középhegység területéről.

A herbáriumi revízióim során ugyanakkor az A. nemorensis-nek mind ez ideig ismeretlen példányát sikerült fölfedeznem a Bakonyicum-ban. A Bakonyból (Vesprimense), Márkó közeléből származik Pillitz Benő 1901-ben gyüjtött, de tévesen határozott lapja („,Csapberki erdő", 5.VI.1901, BP 252122, Arabis glabra néven). E gyüjtését PILLITZ (1908-1910), tévesztése folyományaként, Turritis glabra-ként publikálta.

Egyébként a Bakonyaljáról is előkerült egy tévesen határozott példány, Gotthárd Dénes herbáriumából („Nyirád, Sárosfői-erdő, nedves tölgyesben”, 20.V.1974, GYÖ s.n., Arabis hirsuta ssp. sagittata néven). Habár a Bakonyalját tájföldrajzilag a Bakonyhoz sorolják, növényföldrajzilag a Saladiense flórajárásba tartozik (TALLós 1960). E példányra a DélDunántúl fejezetben utalok.

Kétség merülhet fel Gotthárd Dénes csákvári gyűjtésének lokalizálásával, ill. növényföldrajzi besorolásával kapcsolatban is. A példány talán a Csíkvarsai-rétről származhat, amelyet - az egész Zámolyi-medencével együtt - Soó (1960) elnagyolt térképe látszólag a Bakonyicum flóravidékébe olvaszt, habár a szöveges részben a Mezőföldet („Vértesaljáig”) az Eupannonicum-ba sorozza. Az utóbbi beosztást elfogadva, KEvEY et al. (2015) felfogásával összhangban, az előfordulást az Alföldnél tárgyalom.

\section{Nyugat-Dunántúl (Praenoricum)}

„Kőszeg”, mint lelőhely, először Soó (1968) szinopszisában bukkant föl. Az adat forrása után nyomozva kiderült, hogy ez esetben tévedésről lehet szó. Soó (1968) ugyanis az A. hirsuta ssp. gerardi alá vonta - „var. intermedia (Erdner) Vollm.” néven - Tuzson (1916) A. hirsuta f. austriaca-ját, így az utóbbi néven Tuzson által citált kőszegi adatot is bizonyára a növé- 
nyünkre vonatkoztatta. Tuzson „f. austriaca”-ja azonban semmiképpen nem azonosítható az A. nemorensis-szel. A Tuzson (1916) által revideált és citált négy példány közül hármat láttam, ezek mind az A. hirsuta vagy $A$. sagittata \pm épszélű levelű formáit mutatják. Így a Waisbecker által gyüjtött, $A$. sagittata-ként cédulázott, és Tuzson által „A. hirsuta f. austriaca” néven revideált példány is („Kőszeg vidéke. Ó-Hadasz erdő szélén”, 15.VI.1890, BP 73152), amelyik ráadásul osztrák oldalról származik (Ó-Hadasz = Óhodász, németül Althodis, ma Markt Neuhodis része). Találtam egy másik, szintén Waisbecker által gyüjtött és $A$. sagittataként cédulázott példányt is, amelyet utóbb ő maga revideált $A$. gerardi Bess. névre („Steinbruch in Güns”, 9.VI.1891, BP 73194). Habár ezt a példányt Tuzson nem revideálta, tehát a dolgozatában (Tuzson 1916) nem citálta, elméletileg lehetséges, hogy Soó figyelembe vette a szinopszis összeállítása során. A lelőhely bizonyára a magyar oldalról származik, a példány azonban $A$. sagittata (a vegyes tartalmú lapon egy érett terméses és két fiatal példány található). Miután Kőszeg vidékéről az A. nemorensis-nek egyetlen hiteles adata sincs, KIRÁLY (1996) is csak a szinopszisra hivatkozik, a kőszegi adat törlendő.

\section{Dél-Dunántúl (Praeillyricum)}

A Soó (1968) által jelzett zalai („É- és D-Zala”), valamint „Balaton-part”-i adatoknak nem találtam nyomát az 1968 előtti publikációkban (pl. BoRBÁs 1900, HoRVÁt 1942). A szinopszis adatai minden bizonnyal Károlyi Árpád azon - eredetileg $A$. hirsuta-ként cédulázott - növénytári példányain alapulnak, amelyeket, a cédulákra írt megjegyzés szerint, Pócs Tamás és Balogh Márton utóbb „ssp. gerardi” néven revideált. Ismét csak föltételezem, hogy ezek a revíziók személyes közlés révén Soó tudomására jutottak a szinopszis összeállítása során.

A három zalai példány (Vasboldogasszony, 3.V.1953, BP 298108; Zalaújlak, 9.V.1951, BP 298112; Nagykanizsa és Szepetnek között, 28.V.1949, BP 298111) négy évvel a szinopszis megjelenése után KÁROLYI et al. (1972: 382) flóraművében A. hirsuta ssp. Gerardii néven publikálásra is került. Az adatok után feltüntetett „K.” monogram nyilván a gyűjtőre, Károlyira utal.

Hasonló módon, Soó (1968) Balaton-parti lelőhelye valószínűleg a Károlyi által Balatonmária-alsó (ma: Máriahullámtelep) vasútállomása mellett szedett példányon (12.V.1956, BP 298114) alapul. Utóbbi adatot Károlyi és munkatársai nem publikálták, hiszen a „DélnyugatDunántúl flórája” sorozat területi lefedése a Zákány-Őrtilosi-dombsor kivételével nem terjedt ki Somogy megyére (vö. KárolYI \& Pócs 1969: 377).

Az említett négy példányból egyedül a nagykanizsai példány $A$. nemorensis; a többi $A$. hirsuta vagy $A$. sagittata. Következésképpen Soó (1968) Balaton-parti, továbbá zalai adatainak egy része törlendő. A korrekt nagykanizsai lelőhely a Saladiense flórajárásba tartozik, akárcsak a már említett lesenceistvándi (Soó, 4.VI.1928, KBM 4101) és nyirádi (Gotthárd, 20.V.1974, GYÖ s.n.), továbbá az eddig szintén rejtve maradt tapolcai („in pratis ad Tapolca”, Lengyel, 15.VI.1914, BP 355258, A. sagittata néven), hévízi („Hévízi rét”, s.coll., 14.VII.1902, JPU s.n., A. gerardi néven; „in pratis turfosis circa lacum Hévízi tó”, Rigler, 14.V.1930, DE s.n., A. hirsuta néven) és keszthelyi („Fenékpuszta, Diás-sziget”, Máthé, 10.VI.1945, BP 718395, Turritis glabra néven) példányok. A felsoroltak közül a legrégebbi (1902), lényegében pontosan határozott hévízi példány minden bizonnyal Gállik Oszváld Ödön gyűjtése, aki soproni gimnáziumi igazgatói működése idején botanizált Keszthely és Hévíz környékén (vö. VöRösS 1975).

Élőhelyi útmutatásom alapján a fajt 2018 júniusában Bauer Norbert is megszedte a zalai Hahót mellett, Salix cinerea-s füzlápban (det. Somlyay). Az anyag feldolgozás alatt áll.

E helyütt rövid kitérőt érdemes tenni egy baranyai gyűjtés kapcsán, jóllehet Simonkai Lajos Mecseknádasd mellett szedett és A. nemorensis néven cédulázott példánya („In 
silvarum margine vallis Altergrund prope Nádasd", 28.VII.1873, BP 73146) szerencsére nem rögzült a faj irodalmi adatai között. Ennek valószínű oka, hogy ő maga „A. hirsuta var. glaberrima"-ként publikálta azt (SIMKOvics 1876: 176). Száz évvel később Horvát Adolf Olivér „A. hirsuta glabra”-ként (HoRvát 1943), újabb harminc év múlva „A. hirsuta (L.) Scop. ssp. sudetica (Tausch) Oborny" néven (HoRvát 1975: 27) elevenítette fel Simonkai adatát. Utóbbi név azonban tévedés, hiszen a csaknem kopasz hajtású, és a szubalpin régióra korlátozódó $A$. sudetica Tausch nem fordul elő Magyarországon (vö. Titz 1978, JALAS \& SUOMInEN 1994, KARL \& KoCH 2014). Simonkai példánya a revízióm alapján A. sagittata.

\section{Alföld (Eupannonicum)}

E hatalmas tájegységből Soó (1968) csak a Tuzson (1916) által tisztázott Duna-menti adatokat (Csepel-sziget, Dunapataj, Ercsi, Kalocsa) és Kovács \& PrISZTER (1957) péceli adatát ismerte. Ezeket két flórajárásba sorolta, az előbbieket a Dunavidékhez (Colocense), a pécelit a Duna-Tisza-közéhez (Praematricum). Eltekintve attól, hogy e flórajárások elkülönítésének (Soó 1960) létjogosultsága vitatható - NB. az 1951-es vácrátóti szimpóziumon a két flórajárást még egyetlen növényföldrajzi egységként („Dunavidék”) definiálták (vö. JávoRKA \& Soó 1951, Boros 1952, 1953, KÁRPÁTI 1960) -, a péceli lelőhelyet Kovács \& PRISZTER (1957) a Gödöllői-dombság részeként egyenesen az Északi-középhegység (Matricum) nógrádi flórajáráshoz (Neogradense) sorolta. Ez utóbbi adat egyébként egy harmadik személy levélbeli közlésén alapul („Dévényi P. in litt.”), bizonyító példánya nem ismert, megerősítésre szorul.

Amennyiben követjük a Soó-féle Colocense - Praematricum felosztást, és elfogadjuk a (kétes) péceli lelőhelyet a Neogradense részeként, úgy a faj jelenleg ismert hazai alföldi előfordulásai az Arrabonicum, a Colocense és a Nyírségense flórajárásokra korlátozódnak. Mielőtt ezeket tárgyalom, ki kell térnem JALAS \& SUOMINEN (1994) térképére, amely a taxont a Duna bal oldaláról, Vác környékéről is jelzi. Ez a pont valószínűleg Kárpáti Zoltán alsógödi példányán alapul, amelyet 1938. május 18-án gyűjtött és $A$. hirsuta ssp. planisiliqua néven cédulázott (BP 389096). E herbáriumi adatot föltehetően a „Mapping the Flora of Europe” projekt akkori magyar referense közölte a helsinki központtal. Revízióm szerint a növény $A$. sagittata.

Az Arrabonicum területéről (a Hanságból és a Fertő-medencéből) formálisan csak nemrég publikálták az A. nemorensis előfordulásait (KIRÁLY \& KIRÁLY 2006, 2018). Ugyanakkor ide tartozik Lengyel Géza 1910-es gyűjtése Fertőd-Eszterháza térségéből (BP 355259, BP 355263), amelyet $A$. sagittata-ként cédulázott, továbbá Polgár Sándor 1926-os példánya (BP $262 \ldots$.. [?], BP 262674, DE s.n.) Lébény mellől (Bormászi-erdő). Polgárnak két releváns lapja található a Növénytárban, az egyik $A$. hirsuta-ként, a másik $A$. hirsuta ssp. planisiliqua-ként cédulázva. E lapokon a jobb oldali tövek $A$. nemorensis-szek, a bal oldaliak $A$. hirsuta-k. Polgár nyilvánvalóan helyesen határozta meg a növénytári példányait - amit a debreceni példány is tanúsít -, azok a felragasztáskor keveredhettek össze. Mivel a lébényi lelőhely a történelmi Moson vármegye területére esik, a Győr megyei flóramúben (PoLGÁr 1941: 273) ez az adat nem szerepel. A faj nemrégiben a Marcal-medencéből is előkerült, az egeraljai „Jánosi-Bozót” égeres láperdejében Sinigla Mónika gyűjtötte 2014-ben.

A Colocense-ből, mint láttuk, a faj régóta ismert. A Tuzson (1916) által idézett herbáriumi példányok mellé sorakozik Lengyel Géza eddig nem felismert szigetszentmiklósi gyüjtése 1933-ból (BP 355024, BP 355025, A. hirsuta néven). Megjegyzem, Tauscher Gyula ercsi példánya („Comitatus Alba. E fruticetis insula danubialis prope oppidum Ercsi”, V.1869, BP 73026) valószínűleg az egykori Ercsi-szigetről származik, nem pedig a Csepel-szigetről, amiként azt TUZson (1916) értelmezte. Újabban, alfaji rangon, STETÁK (2005) közölte a bajai Pörböly-erdőből (bizonyító példánya: BP 597169), ahol egyébként Jávorka Sándor, Kárpáti Ist- 
ván és Csapody Vera már 1957-ben gyújtötték a növényt (BP 208570). Eddig rejtve maradtak viszont a faj zámolyi-medencei (Csákvár), sárréti (Sárszentmihály) és turjánvidéki (Kiskőrös, Ócsa) előfordulásai. A csákvári példány („Csákvár Hajduvágás előtti réten”, Gotthárd, 12.V.1979, GYÖ s.n., Arabis hirsuta f. subglabrata néven) lokalizálásával kapcsolatos nehézségre már utaltam. Sárszentmihálynál („Hermina-puszta” = Herminamajor) Filarszky Nándor és Kümmerle J. Béla gyújtötték 1923-ban, a példányukat (BP 73145) A. nemorensis néven (!) cédulázták. Nemrég Sramkó Gábor szedte ezen a környéken („regenerálódó szántó”, 24.V.2009, DE s.n., A. hirsuta néven) (vö. TAKÁcs et al. 2014). Kiskőrös mellett („Tabdi-erdő”) Boros Ádám gyűjtötte 1925-ben, de a példány (BP 429395) céduláját név nélkül hagyta, naplójába pedig $A$. hirsuta néven jegyezte fel az adatot. Nyilván ez az oka, hogy releváns dolgozataiban (BoROs 1936, 1952) nem említette növényünket. Ócsán először Soó Rezső és Borsos Olga gyüjtötték („in pratis uliginosis pr. pag. Ócsa”, 10.VI.1953, BPU s.n.), az eredetileg A. hirsuta-ként cédulázott lapot ismeretlen személy utólag „ssp. planisiliqua”-ként revideálta. Tudtommal ennek az adatnak sem maradt irodalmi nyoma, NóTÁRI et al. (2017) áttekintésében a példány $A$. hirsuta néven szerepel. A következő ócsai gyưjtés Gotthárd Dénes nevéhez füződik („Ócsa-szöllők vm.-nál ligeterdőben”, 14.VI.1980, GYÖ s.n., A. hirsuta néven). KIRÁLY \& KIRÁLY (2018) saját ócsai adatuk kapcsán egyik régi példányt sem említik, hajósi és homokmégyi adatuk viszont új a flórajáráson belül.

A Nyírségense, sőt az egész Tiszántúl területéről a fajt eddig nem ismertük (vö. Boros 1932, Soó \& MÁTHÉ 1938, Soó 1968). A Tócó-patak mellé települt debreceni szennyvíztelepen Siroki Zoltán 1970-ben gyüitött és $A$. hirsuta-ként cédulázott példányai (vö. TAKÁcs et al. 2015) azonban kétségtelenül $A$. nemorensis-szek. Növényünk föltehetően a botanikailag értékesebb patak menti növényzetben tenyészhetett, habár Tiтz (1969b) szerint a faj olykor ruderális élőhelyen is előfordul.

Az A. nemorensis alföldi előfordulásai kapcsán külön kell foglalkozni SzujKó-LACZA \& Kováts (1993) flóraművének adataival. Mivel a flóramú által lefedett terület, címével ellentétben, a földrajzi értelemben vett Duna-Tisza-köze legnagyobb részére (a Budapest - Szolnok vonaltól délre) kiterjed, az enumerációban a taxon Duna bal parti oldaláról származó adatainak elvileg szerepelnie kéne. A flóramű azonban az $A$. hirsuta alakköréből csak az „A. gerardii” és az „A. hirsuta ssp. sagittata” taxonokat ismeri. A gyanútlan olvasónak az az érzése támadhat, hogy növényünk nem is olyan ritka a Duna-Tisza-közén, holott az A. gerardii név alatt a flóramű szerzői nyilvánvalóan összemosták az $A$. hirsuta s. str. és $A$. nemorensis fajokat. Mi több, amint arról a revízió során meggyőződtem, ebből az adathalmazból az $A$. sagittata (alfaji rangú) leválasztása sem következetesen történt. Mindezt tetézi, hogy az enumerációban bizonyító példánnyal nem alátámasztott irodalmi és kéziratos adatokat is találunk. Magam biztosra veszem, hogy az A. gerardii név alatt felsorolt tételek közül csak Tauscher Gyula 1868-as, 1871-es és 1875-ös, valamint Vajda László 1936-os szigetúffalui, továbbá Lengyel Géza 1933-as szigetszentmiklósi gyűjtései vonatkoznak valóban $A$. nemorensis-re. Az enumerációból ugyanakkor releváns növénytári példányok (Baja, Kiskőrös) és irodalmi források (BORBÁs 1879, Tuzson 1916) hiányoznak.

\section{Néhány A. nemorensis adat a szomszédos országokból}

A Növénytár „Herbarium Carpato-Pannonicum” gyűjteménye Arabis-anyagának revíziója során a jelenlegi országhatáron kívülről származó $A$. nemorensis példányok is előkerültek. Mivel ezek a szakirodalom számára ismeretlen, történeti értékű adatok, röviden tárgyalom őket. 


\section{Románia (Erdély)}

NYÁRÁDY (1955: 304) a taxon romániai lelőhelyeként egyedül a Körösvidéket (Crişana) jelölte meg. JALAS \& SUOMINEN (1994: 189) elterjedési térképén viszont egyáltalán nincs romániai pont. CIOCÂRLAN (2000) ismét csak a Körösvidéket említette. OpREA (2005) összegyüjtötte a taxonra vonatkoztatható összes romániai irodalmi adatot. Ennek folyományaként CiocÂRLAN (2009) és SÂRBU et al. (2013) munkáiban a Körösvidék mellett Szeben és Hunyad megyék, továbbá Bukovina (Szucsáva, Ráró-hegység) is felsorolásra kerültek. Feltűnő, hogy az említett régiókat gyakorlatilag csak egy-egy irodalmi adat reprezentálja. E helyütt nem célom ezek kritikai felülvizsgálata, de a bizonyító példány nélküli adatokat fenntartással kell fogadnunk.

Mindenesetre a most közölt új, Kovászna megyei (Judeţul Covasna) előfordulás Torja (Turia) közeléből („Büdös-hegy” = Vf. Puturosu) két növénytári herbáriumi példánnyal is bizonyított (1. táblázat). Ferdinand Schur gyűjtötte (BP 73128) itt először, 1853-ban, és lényegében helyesen azonosította a növényt (A. gerardi néven). Különös, hogy erdélyi monográfiájában (SCHUR 1866: 43) innen nem, csak Nagyszeben (Hermannstadt) mellől jelzett növényt. Csaknem száz évvel később Jávorka Sándor és Keller Jenő ismét megszedték a fajt a Büdös-hegyen (BP 73032), de adatuk, A. hirsuta néven cédulázva, rejtve maradt.

\section{Szerbia (Vajdaság)}

Habár az Atlas Florae Europaeae (JALAS \& SUOMinen 1994) a taxont Szerbia több térképezési kvadrátjából jelzi, ezek voltaképpen néhány ellenőrizetlen irodalmi közlésen alapulnak (Marjan Niketić, in litt. 2018). Az ország északi, Magyarországgal határos részéből (Vajdaság) teljesen hiányoznak az adatok. Futak erdejéből Schneller (1858) közölt egy „A. nemorensis Wolf." nevű taxont, amelyet Zorkóczy (1896: 41) és ProdAn (1915: 226) is idéztek (az „A. glastifolia Rchb."-val szinonimizálva azt), de bizonyító herbáriumi példány híján a növény azonossága kérdéses.

Az MTM Növénytára anyagának revíziója során viszont rábukkantam egy, A. glastifolia Rchb. néven cédulázott vajdasági példányra (BP 73164), amelyik kétséget kizáróan $A$. nemorensis. Kovács Ferenc plébános gyűjtötte az óbecsei (ma: Bečej) Árpádligetben 1879ben. Sajnos, évtizedek múlva ő maga (Kovács 1929: 91) már a faj kipusztulásáról tudósított: „Flóránkból teljesen kiveszett. Deákkoromban az Árpádligetben még szedtem, most nyoma sincs.” Érdekes, hogy Tuzson „A. hirsuta f. Hornungiana” néven revideálta ezt a példányt, és nem vette észre taxonómiai azonosságát a többi hazai (Csepel-sziget, Dunapataj, Ercsi, Kalocsa) „A. hirsuta f. gerardi” példánnyal, amelyeket maga revideált.

\section{Ausztria (Őrvidék)}

A faj ausztriai elterjedésének súlypontja Alsó-Ausztria (Niederösterreich) keleti, pannóniai területeire és az Őrvidék (Burgenland) északi részére, főként a Fertőzugra (Seewinkel) esik (Titz 1966, 1969b, Grass 1995, AdLER et al. 1996, Fischer et al. 2005). A Fertőzugban Féltorony (Halbturn), Illmic (Illmitz), Mosonszentandrás (Sankt Andrä), Mosontarcsa (Andau) és Mosontétény (Tadtem) környékéről Melzer (1961), TrAXLER $(1963,1964)$ és TiTz (1966, $1969 b$ ), északabbra, Zurány (Zurndorf) és Németjárfalu (Jahrndorf) körzetéből ADLER et al. (1996) közölték. 
E sorozathoz csatlakozik Lengyel Géza pomogyi (Pamhagen) példánya [,in pratis ad pagum Pomogy", VI.1910 (és VI.1919?), BP 355260, BP 355264, A. sagittata néven], amely történetileg a faj első ismert gyűjtése az Őrvidék területéről.

E vonatkozásban ki kell térnem Uhl János Kismarton (Eisenstadt) környékéről származó, 19. századi „A. gerardi” gyüjtésére, amelyet Gombocz Endre a Sopron megyei flóraművében (Goмвосz 1906: 499) citált [,Kis-Marton mellett (Uhl)”], tehát ő maga látta a példányt. A kalandos sorsú Uhl-herbárium történetét Goмвосz (1906) flóraművéig ismerjük biztosan, BUNKE (1980) szerint végül az MTM Növénytárába került. Utóbbi állítást nem tudom megerősíteni. A Növénytárban ugyan találtam Uhl által gyüjtött lapokat, de ezek Joseph Stanislaus Albach (1795-1853), ferences szerzetes történeti értékủ herbáriumába vannak beosztva. Ráadásul e lapokon Gombocz cédulái is szerepelnek, ami arra utal, hogy Gombocz annak idején egyszerűen „átemelt” néhány Uhl-féle példányt a saját herbáriumába. Ami Albach és Uhl kapcsolatát illeti, 1843 után valóban szoros szakmai együttmüködés alakult ki köztük. A közös gyüjtéseik ellenére azonban saját herbáriumuk volt, egymástól független utóélettel (vö. Goмвосz 1906: 417). Albach herbáriuma 1854-ben került a Nemzeti (a mai Természettudományi) Múzeumba (HuszáR 1944), Uhl herbáriuma a soproni flóramű megjelenésekor (1906) még a „soproni felső kereskedelmi iskola” tulajdonában volt (GomBocz 1906: 455). Mindenesetre a Növénytárban rábukkantam egy példányra (BP 73195), amelyet Uhl és Albach együtt gyűjtöttek Kismarton mellett 1845. május 7-én (a lapon lévő 219-es kollektorszám Gombocz herbáriumi hagyatékára utal). Az eredeti cédulán Arabis gerardi, Gombocz céduláján pedig $A$. hirsuta var. gerardi név szerepel. Maga a bimbós példány minden bizonynyal $A$. sagittata, semmiképpen nem $A$. nemorensis. Mindezek alapján valószínüsíthető, hogy a Gомвосz (1906) által idézett Uhl-féle „A. gerardi” példány, akárcsak a korábban már említett Wallner-féle soproni adat, nem A. nemorensis-t takar.

\section{Köszönetnyilvánítás}

Dolgozatom elkészítésében alapvető segítséget kaptam azoktól a kollégáktól, akik a felügyeletük alatt álló herbáriumból a releváns példányokat számomra lefényképezték, esetenként pedig a kritikus példányokat az útmutatásom alapján ellenőrizték: Ballók Zsuzsanna (Gyöngyös), Balogh Lajos (Szombathely), Csiky János (Pécs) és Sinigla Mónika (Zirc). Külön említem Samu Zoltán Tamás (Keszthely, Balaton Múzeum) áldozatos munkáját, aki a habitusfotók mellett makrofotók készítésére is vállalkozott. Különböző módon segítették a munkámat Bauer Norbert (Budapest), Horváth Csaba (Sopron), Lovas-Kiss Ádám (Debrecen), Nagy Tímea (Keszthely), Németh Péter (Keszthely), Papp László (Budapest), Penksza Károly (Gödöllő), Sramkó Gábor (Debrecen) és Takács Attila (Debrecen). Utóbbi kolléga segítsége nélkül az elterjedési térkép sem készülhetett volna el. Marjan Niketić (Beograd) a taxon szerbiai irodalmi elterjedési adatairól tájékoztatott. Mindannyiuknak hálás köszönetemet fejezem ki! Munkámat az OTKA K108992 számú pályázata támogatta.

\section{Irodalomjegyzék}

Adler W., Fischer M. A. \& Schratt-Ehrendorfer L. (1996): Floristisches aus Oberösterreich, Niederösterreich und Wien. - Florae Austriacae Novitates 4: 18-31.

BorbÁs V. (1878): Vizsgálatok a hazai Arabisek és egyéb cruciferák körül. - Mathematikai és Természettudományi Közlemények 15: 145-211.

Borbás V. (1879): A főváros és környékének növényzete. - In: Gerlóczy Gy. \& DulácskA G. (szerk.), Budapest és környéke természetrajzi, orvosi és közmivelódési leirása, Magyar Királyi Egyetemi Könyvnyomda, Budapest, pp. 117-286. 
BorBás V. (1900): A Balaton tavának és partmellékének növényföldrajza és edényes növényzete. - A Balaton tudományos tanulmányozásának eredményei, Hornyánszky Viktor kny., Budapest, 432 pp. + I-III. tábla.

Boros Á. (1932): A Nyírség flórája és növényföldrajza. - A Tisza István Tudományos Társaság Honismereti Bizottságának Kiadványai 7 (1930-1931): 1-208.

Boros Á. (1936): A Duna-Tisza köze kőriserdői és zsombékosai. - Botanikai Közlemények 33: 84-97.

Boros Á. (1952): A Duna-Tisza-köze növényföldrajza. - Földrajzi Értesítö 1: 39-53.

Boros Á. (1953): A Mezőföld növényföldrajzi vázlata. - Földrajzi Értesítő 2: 234-250.

BunKe Zs. (1980): Stanislaus Albach botanikai munkássága. - Botanikai Közlemények 67 (3): 227-236.

CioCÂRlan V. (2000): Flora Ilustrată a României: Pteridophyta et Spermatophyta. - Ceres, Bucureşti, $1138 \mathrm{pp}$.

CioCÂRlan V. (2009): Flora Ilustrată a României: Pteridophyta et Spermatophyta. - Ceres, Bucureşti, $1141 \mathrm{pp}$.

Domac R. (2002): Flora Hrvatske. - Školska knjiga, Zagreb, 504 pp.

DosTÁL J. (1948-1950): Květena ČSR a ilustrovaný klíč $k$ určení všech cevnatých rostlin, na území Československa planě rostoucích nebo běžně pěstovaných. - Přírodovědecké nakladatelství, Praha, $2269 \mathrm{pp}$.

FisCHER M. A., AdLER W. \& OsWALD K. (2005): Exkursionsflora für Österreich, Liechtenstein und Südtirol. Land Oberösterreich, Biologiezentrum der OÖ Landesmuseen, Linz, 1392 pp.

Gомвосz E. (1906): Sopronvármegye növényföldrajza és flórája. - Mathematikai és természettudományi Közlemények 28 (4): 401-579.

Grass V. (1995): Katalog der "Prioritären" und "Streng Geschützten" Pflanzenarten des Arten- und Lebensraumschutzprogrammes der Stadt Wien. - ARGE für Vegetationsökologie und angewandte Naturschutzforschung, Wien, 112 pp.

HAZSLINSZKY F. (1872): Magyarhon edényes növényeinek füvészeti kézikönyve. - Athenaeum, Pest, 504 pp.

Hoffmann G. F. (1804): Deutschlands Flora oder Botanisches Taschenbuch für das Iahr 1804. - Iohann Iacob Palm., Erlangen, 308 pp.

HoRVÁt A. O. (1942): Külsősomogy és környékének növényzete. - Borbásia 4 (1-6): 1-70.

HoRvát A. O. (1943): Pótlások „A Mecsekhegység és környékének flórájá”-hoz (1941). Addimenta ad floram regionis montium Mecsek. - Botanikai Közlemények 40 (1-2): 101-112.

HoRvÁt A. O. (1975): Pótlások és kiegészítések „A Mecsek-hegység és déli síkjainak növényzete” ismeretéhez I. (1942-1971). - Janus Pannonius Múzeum Évkönyve 17-18 [1972-1973]: 15-32.

Huszár I. J. (1944): P. Albach J. Szaniszló O. F. M. (1795-1853): - Értekezések a M. Kir. Horthy Miklós Tudományegyetem Magyar Történelmi Intézetéből 5: 1-92.

Jalas J. \& Suominen J. (ed.) (1994): Atlas Florae Europaeae 10. Cruciferae (Sisymbrium to Aubrieta). Helsinki University Printing House, Helsinki, 224 pp.

Jávorka S. (1924-1925): Magyar Flóra (Flora Hungarica). - Studium, Budapest, 1307 pp.

JÁVORKA S. (1926): A magyar flóra kis határozója. - Studium, Budapest, 324 pp. + I-XLVII. tábla.

JávoRKA S. (1937): A magyar flóra kis határozója. - 2. kiadás, Studium, Budapest, 346 pp.

JávoRKA S. \& Soó R. (1951): A magyar növényvilág kézikönyve I-II. - Akadémiai Kiadó, Budapest, 1120 pp.

JäGER E. J. (ed.) (2017): Rothmaler - Exkursionsflora von Deutschland, Gefässpflanzen: Grundband. Springer-Verlag, Berlin Heidelberg, $930 \mathrm{pp.}$

KarL R. \& Косн M. (2014): Phylogenetic signatures of adaptation: the Arabis hirsuta species aggregate (Brassicaceae) revisited. - Perspectives in Plant Ecology, Evolution and Systematics 16: 247-264.

KÁRoLYi Á. \& Pócs T. (1969): Délnyugat-Dunántúl flórája II. - Acta Academiae Paedagogicae Agriensis 7: 329-390.

Károlyi Á., Pócs T. \& Balogh M. (1972): Délnyugat-Dunántúl flórája V. - Acta Academiae Paedagogicae Agriensis 10: 373-400.

KÁRPÁTı Z. (1960): Die Pflanzengeographische Gliederung Transdanubiens. - Acta Botanica Academiae Scientiarum Hungaricae 6 (1-2): 45-53.

KERNER A. (1867): Die Vegetations-Verhältnisse des mittleren und östlichen Ungarns und angrenzenden Siebenbürgens. IV. - Oesterreichische Botanische Zeitschrift 17 (8): 250-260.

Kevey B., Horváth A., Lendvai G., Simon Gy. \& Sonnevend I. (2015): A Zámolyi-medence és környékének zárt lösztölgyesei (Pulmonario mollis-Quercetum roboris Kevey 2008). - Botanikai Közlemények 102 (1-2): 85-129.

KIRÁLY G. (1996): A Kőszegi-hegység edényes flórája. - Tilia 3: 1-414. 
KIRÁLY G. \& KiRÁLY A. (2006): Adatok és kiegészítések a magyar flóra ismeretéhez II. - Kitaibelia 10 (1): 88-103.

KIRÁLY G. \& KirÁLY A. (2018): Adatok és kiegészítések a magyar flóra ismeretéhez III. - Botanikai Közlemények 105 (1): 27-96.

KiRÁlY G., ViróK V. \& MolnÁR V. A. (szerk.) (2011): Új magyar füvészkönyv. Magyarország hajtásos növényei. Ábrák. - Aggteleki Nemzeti Park Igazgatóság, Jósvafő, 676 pp.

KISS Á. (1939): Adatok a Hegyalja flórájához. - Botanikai Közlemények 36 (5-6): 181-278.

KovÁcs F. (1929): Óbecse határának virágos növényei. - Szeged Városi Nyomda és Könyvkiadó Rt., Szeged, $190 \mathrm{pp}$.

KovÁcs M. (1962): Die Moorwiesen Ungarns. - Akadémiai Kiadó, Budapest, 214 pp. + Tab. I-XXIV.

KovÁCS M. \& PRISZTER Sz. (1957): Kiegészítések és adatok „A magyar növényvilág kézikönyvé”-hez. Botanikai Közlemények 47 (1-2): 87-93.

LÁjER K. (2007): A Nagyberek flórájának és lápi-mocsári vegetációjának alapvonásai. - Natura Somogyiensis 10: 73-93.

Melzer H. (1961): Floristisches aus Niederösterreich und dem Burgenland, III. - Verhandlungen der zoologisch-botanischen Gesellschaft in Wien 100: 184-197.

MENYHÁRT L. (1877): Kalocsa vidékének növénytenyészete. - Hunyadi Mátyás Intézete, Budapest, 198 + 25 pp.

NAGY L. (2006): A Mátra Múzeum herbáriuma - A Gotthárd gyüjtemény IV. (Lythraceae Polygonaceae). - Folia Historico Naturalia Musei Matraensis 30: 91-100.

NAGY T., TAKÁcS A. \& BódIS J. (2016): Magyar herbáriumok 15. A keszthelyi Balatoni Múzeum herbáriuma (KBM). - Botanikai Közlemények 103 (2): 213-226. (elektronikus melléklet)

NeILREICH A. (1866): Aufzählung der in Ungarn und Slavonien bisher beobachteten Gefässpflanzen nebst einer pflanzengeografischen Uebersicht. - Wilhelm Braumüller, Wien, 390 pp.

NeILREICH A. (1870): Aufzählung der in Ungarn und Slavonien bisher beobachteten Gefässpflanzen. Nachträge und Verbesserungen. - Wilhelm Braumüller, Wien, $111 \mathrm{pp}$.

NótÁRI K., NAGY T., LÖKI V., LJUBKA T., MolnáR V. A. \& TAKÁcs A. (2017): Az ELTE Füvészkert herbáriuma (BPU). - Kitaibelia 22 (1): 55-59. (elektronikus melléklet)

NYÁRÁdy E.I. (1955): Cruciferae. - In: SĂvulescu T. (ed.), Flora Republicii Populare Romîne III., Acad. Rep. Pop. Romîne, Bucureşti, pp. 102-501.

OPREA A. (2005): Lista critică a plantelor vasculare din România. - Universității „Alexandru Ioan Cuza”, Iași, $668 \mathrm{pp}$.

Pillitz B. (1908-1910): Veszprém vármegye növényzete. - Krausz Armin fia könyvnyomdája, Veszprém, $139 \mathrm{pp}$.

PolGÁR S. (1941): Győrmegye flórája. Flora Comitatus Jaurinensis. - Botanikai Közlemények 38: 201-352.

ProdAn J. (1915): Bács-Bodrog vármegye flórája. - Magyar Botanikai Lapok 14: 120-269.

SÂRbu I., ȘTEFAn N. \& OpREA N. (2013): Plante Vasculare din România: determinator ilustrat de teren. Editura Victor B Victor, Bucureşti, 1320 pp.

SCHNELLER W.A. (1858): Beitrag zur Kenntniss der phanerogamen Flora von Futak bei Peterwardein. Verhandlungen des Vereins für Naturkunde zu Presburg 3 (1): 1-22.

ScHuR F. (1866): Enumeratio plantarum Transsilvaniae. - Guilielmum Braumüller, Vindobonae, 984 pp.

Simon T. (1992): A magyarországi edényes flóra határozója, Harasztok - Virágos növények. Tankönyvkiadó, Budapest, 892 pp.

Simon T. (2000): A magyarországi edényes flóra határozója. - Tankönyvkiadó, Budapest, 976 pp.

Simkovics (SimONKAI) L. (1876): Adatok Magyarhon edényes növényeihez. - Mathematikai és Természettudományi Közlemények 11 [1873]: 157-211.

Soó R. (1930): Adatok a Balatonvidék flórájának és vegetációjának ismeretéhez. II. - A Magyar Biológiai Kutatóintézet Munkái 3 (1): 169-185.

Soó R. (1940): A Sátorhegység flórájáról. - Botanikai Közlemények 37: 169-187.

Soó R. (1943): Előmunkálatok a Bükkhegység és környéke flórájához. - Botanikai Közlemények 11 (3-4): 169-221.

Soó R. (1960): Magyarország új florisztikai-növényföldrajzi felosztása. - A Magyar Tudományos Akadémia Biológiai Csoportjának Közleményei 4 (1-2): 43-70.

Soó R. (1968): A magyar flóra és vegetáció rendszertani-növényföldrajzi kézikönyve III. - Akadémiai Kiadó, Budapest, 506 pp.

Soó R. \& MÁTHÉ I. (1938): A Tiszántúl flórája. - Instituti Botanici Universitatis Debreceniensis, Debrecen, $192 \mathrm{pp}$. 
ŠTĚPÁNEK J., GOLIAŠOVÁ K. \& HodÁlovÁ I. (2002): Arabis L. - In: GoliAšovÁ K. \& ŠíPoŠovÁ H. (eds), Flóra Slovenska V/4, VEDA vydavatel'stvo Slovenskej akadémie vied, Bratislava, pp. 415-454.

STETÁK D. (2005): A Duna-Dráva Nemzeti Park Gemenci Tájegysége mocsári és mocsárréti növénytársulásairól. - Botanikai Közlemények 92 (1-2): 119-157.

SzujKó-LaCZA J. \& Kováts D. (szerk.) (1993): The flora of the Kiskunság National Park. - Magyar Természettudományi Múzeum, Budapest, 469 pp.

TALLós P. (1960): Növényföldrajzi és florisztikai adatok a Dunántúlról. - Botanikai Közlemények 48: 77-80.

TAKÁCS A., NAGY T., FEKETE R., LOVAS-Kiss Á., LJUBKA T., LÖKI V., LisZTES-SZABó Zs. \& MolNáR V.A. (2014): A Debreceni Egyetem Herbáriuma (DE) I.: A „Soó Rezső Herbárium”. - Kitaibelia 19 (1): 142-155. (elektronikus melléklet)

TAKÁCS A., SÜVEges K., LJUbKA T., LÖKI V., LisZTEs-SZabó Zs. \& MolnáR V.A. (2015): A Debreceni Egyetem Herbáriuma (DE) II.: A „Siroki Zoltán Herbárium”. - Kitaibelia 20 (1): 15-22. (elektronikus melléklet)

Tiтz W. (1966): Neue österreichische Fundorte von Agropyron-, Bromus- und Arabis-Arten sowie deren Chromosomezahlen. - Österreichische Botanische Zeitschrift 113: 470-475.

Tiтz W. (1969a): Zur Cytotaxonomie von Arabis hirsuta agg. (Cruciferae). II. Morphologische Analyse österreichischer Populationen und die Abgrenzung der Sippen. - Österreichische Botanische Zeitschrift 117: 21-53.

TiтZ W. (1969b): Zur Cytotaxonomie von Arabis hirsuta agg. (Cruciferae). III. Verbreitung, Standorte und Vergesellschaftung der Sippen in Österreich und phylogenetische Hinweise. - Österreichische Botanische Zeitschrift 117: 87-106.

Tiтz W. (1972): Evolution of the Arabis hirsuta group in central Europe. - Taxon 21 (1): 121-128.

Tiтz W. (1976): Die ost- und mitteleuropäische Tieflandsart Arabis nemorensis (Hoffm.) Koch ist von $A$. planisiliqua (Pers.) Reichenb. abzutrennen. - Linzer biologische Beiträge 8 (2): 347-356.

Tiтz W. (1978): Über das Vorkommen von Arabis sudetica Tausch (Brassicaceae) in den Ostalpen. Carinthia II 168/88: 275-278.

TraXler G. (1963): Die Flora des Leithagebirges und am Neusiedlersee. 6. Ergänzung zum gleichnamigen Buch von Karl Pill. - Burgenländische Heimatblätter 25: 1-15.

Traxler G. (1964): Die Flora des Leithagebirges und am Neusiedlersee. 7. Ergänzung zum gleichnamigen Buch von Karl Pill. - Burgenländische Heimatblätter 26: 2-18.

Tuzson J. (1916): Az Arabis hirsuta (L.) Scop. alakjai. - Mathematikai és Természettudományi Értesítő 34 (3-4): 412-430.

Tuzson J. (1921): Die Formen der Arabis hirsuta (L.) Scop. - In: Bericht der Freien Vereinigung für Pflanzengeographie und systematische Botanik für das Jahr 1919, Verlag Max Lande, Berlin, pp. 15-44.

VојтKó A. (szerk.) (2001): A Bükk hegység flórája. - Sorbus 2001 Kiadó, Eger, 340 pp.

Vöröss L.Zs. (1975): A pannonhalmi herbárium törzsgyújteménye 1. - A Pécsi Tanárképző Fóiskola Tudományos Közleményei 19: 31-40.

WALLNER I. (1903): Sopron környékén található virágos növények és edényes cryptogamok nemei és fajai. - In: WALLnER I. (szerk.), A Soproni Magy. Kir. Állami Főreáliskola XXVIII. évi Értesítője, Röttig Gusztáv, Sopron, pp. 1-42.

ZoRKóczy L. (1896): Ujvidék- és környékének flórája. - Saját kiadás, Ujvidék, 128 pp.

Beérkezett / received: 2018. 08.24. • Elfogadva / accepted: 2018. 10. 03. 